\title{
The Value of Good Liturgical Music
}

\author{
Cordis-Mariae Achikeh \& Raphael Umeugochukwu \\ http://dx.doi./org/10.4314/ujah.v20i3.8
}

\begin{abstract}
It is disturbing that in recent times, the worshiping community in the capacity of some church ministers, composers and musicians have deviated from the specifications of liturgical music even as recommended by Vatican Council II (The Constitution of The Sacred Liturgy). Also misunderstood and misappropriated is the idea of inculturation that permits composers in different countries to write music using the language of the locality as well as the indigenous instruments. This is partly due to inadequate enlightenment and training on the part of the liturgical music practitioners on the real meaning of liturgical music. A lot of problems have come up from these misconceptions and misinterpretations which include but a few making noise in place of music, negligence of the core features of liturgical music ranging from little or no attention to the solemn nature of the liturgy to relevance for some unimaginable selfish interests. In remedying these challenges, the researcher has made lots of recommendations. One of them is that the practitioners of liturgical music be exposed through seminars and workshops to relevant church documents on liturgical music from time to time. It is necessary and most pertinent that the church retains its solemnity in worship as against the recent mediocrity which has come to envelop the liturgical music making practices. The great value of good liturgical music needs to be sustained.
\end{abstract}


Keywords: Liturgical Music, Gregorian Chant, Sacred Polyphony, Instrumental Music, Catholic Church, Liturgical Musician, Choir, Congregation.

\section{Introduction}

The music of the liturgy possesses great value. "Good" as presented by the topic goes ahead to state the nature this value should take; it has gone out of the ordinary in the sense that it is not just about liturgical music but a good one. It is also not just talking about good music but good liturgical music. So what about liturgy? In the context of this study, liturgy is defined as community prayer where the people of God come together to worship God as a united group activity reflecting praise, thanksgiving, supplication or repentance. The researcher went further to explain liturgical music as a kind of music used in divine worship as obtainable in the congregational gathering of Roman Catholic Mass, the Anglican Holy Communion Service, the Lutheran Mass, the Orthodox Liturgy and other Christian Services, including the Divine Officer. This article however will be based on the liturgical music of the Catholic Church. Liturgical music therefore would be a music that lives out the liturgy. They are basically in form of chants for instance the Gregorian chants, Sacred Polyphony, Sacred Music for the Organ and other approved instruments and Sacred Popular music approved by the Church. This means that in addition to the already existing repertoires especially the medieval chants which are as old as the church provisions have been made over time for composers contribute to liturgical music following some guidelines and specifications. These musical specifications are expected to meet up with three qualities and prerequisites as stated by Pope Pius $\mathrm{X}$ in his MotusPropio "Tra Le Sollecitudini" 1903 and these qualities 
include Holiness, Artful Beauty and Universality. The music should not in the quest of embodying holiness lack aesthetics and above all should be comprehensive to the worshipping community which will greatly enable their active involvement in the worship.

\section{What then is Liturgical Music?}

Explaining liturgical music first in isolation, music generally is a succession of organized sound that is pleasing to the ear. We can also say in the context of this paper that music is a sacred art because it is used in different churches for worship and liturgy.

Liturgy in other words is derived from a Greek word "Leitourgia" which literally means "Work of the people". It is the customary public worship performed by a religious group. Liturgy can also be defined as community prayer where the people of God come together to worship God as united group reflecting praise, thanksgiving, supplication or repentance. So typically, a liturgical music should serve a purpose of glorifying God and adding value to the spiritual life of the faithful. Liturgical music is therefore the kind of music used in divine worship. It is a form of music originating as a part of religious ceremony.

\section{The Relevance and Roles of Music in the Liturgy}

Why is music being used in liturgical celebrations? Why not use only spoken words without music? Why not use the said Mass"? Why bother with the 'Sung Mass"? Sacred Music has the important role of both as a means of lifting up the spirit to God and as a precious aid for the faithful in their "active participation in the most holy mysteries and in the public and solemn prayer of the Church" - says Pope St Pius X.

The great French Liturgist, Joseph Gellireau said: "If one person in the assembly is not singing, then the praise of God is 
incomplete." According to Liam Newton, an Irish Catholic priest, composer and performer of Sacred and Liturgical music:

- Music is part of the symbolic language of worship.

- Music is a symbol of unity in a worshipping community between the people and their God, and also among people themselves.

- Music can evoke a personal response from us as individuals and can enhance our relationship with God.

- To be present at a liturgy that is void of music and singing can be an empty experience, as "I feel I am not fully communicating with my Creator who has endowed us with the gifts of sound and silence."

Music in the Liturgy, when rendered well, can not only be a way of glorifying God, but can also be a means of:

- Proclaiming the gospel.

- Refuting heresy.

- Promoting and restoring spiritual well-being.

- Catechizing souls.

- Encouraging and helping one another.

- Contribute to healing of souls. Be a source of therapy. For example; within communities struck by disaster or grief, liturgical singing aims at healing people and processing their loss, and ultimately promoting spiritual wellness by restoring or reshaping their picture of God.

- Conversion of souls: When St Augustine was still unconverted and nearly a heretic, he used to slip into the cathedral of the bishop St. Ambrose, not only to hear the holy bishop's homilies, but also to listen to the solemn, calm and soothing songs performed by St Ambrose's choir. The words of the 
liturgical songs kept on sinking into the soul of Augustine until he became converted.

That is why it is very important that Liturgical music be good and well rendered so that its role in the Liturgy would be properly carried out, and its aim achieved.

\section{Kinds of Music that are Worthy to be Used in the Liturgy}

It should be obvious that there is a place for all kinds of music. Not every kind of music can have a place in Christian worship. It has its standard and that standard is God. Do the kind of music we choose for the liturgy lift the heart of man to God, to what is above or rather causes his disintegration into formless intoxication or mere sensuality? That is the criterion for liturgical music. It is highly distracting for a choir to intone an inaccessible medieval anthem or an operatic soprano belting out a Mozart aria within the liturgy. The Vatican II calls for Catholic liturgical music to consist of four types of sacred music: (a) Gregorian Chant, (b) Sacred Polyphony in its various forms, (c) Sacred music for the Organ and other approved instruments, (d) Sacred popular music approved by the Church.

\section{The Gregorian Chant}

The Roman Catholic Church holds the Gregorian chant in great esteem and sees it as the highest model of Church music; above all other musical styles that have surfaced over the $\mathrm{c}$ enturies. The Vatican II recognizes that "being especially suited to the Roman Liturgy, the Gregorian Chant should be given, other things being equal, pride of place (principem locum) in liturgical services." The Church does not favor it for any particular reason, but does so because of its ability to foster prayer. 
Gregorian chant therefore is that Roman form of early Plain Chant. It is the most important branch of plain song and it forms the base in liturgical music. Gregorian chant is sung prayer and must be sung to God in His presence. It conveys a calm, other worldly quality; it represents the voice of the Church, rather than of any single individual. Gregorian chant is also a community prayer and must be prepared carefully so that all who take part in it will sing as a united group. It comprises of not only the Church music of the early Middle Ages but also later compositions (elaborate melodies for the Ordinary of the Mass, sequences, etc) written in a similar style down to the Sixteenth Century and even in modern times. Gregorian Chant is named after Pope St Gregory the Great who in the $6^{\text {th }}$ Century, effected a certain final arrangement and liturgical organization of the Roman Chant, during his reign from 590 to $604 \mathrm{AD}$.

Though Gregorian Chant has some similarities with pure music, yet they differ in many way for instance; Gregorian Chant uses Latin texts, The chant is purely melody; all the parts sing the same melody but in different pitches, It enjoys free rhythm -Its rhythm is flexible, without meter, and has little sense of beat, its musical notes are called Neums, Gregorian Chant musical staff has only 4 lines and 3 spaces, Gregorian Chant enjoy 8 modes, Gregorian Chant is notated on the chant staff using keys C Major and $\mathrm{F}$ Major; when on $\mathrm{C}$ Major, $\mathrm{C}$ is the doh, and when on $\mathrm{F}$ Major, $\mathrm{F}$ is the fah and so on.

The exclusive nature of Gregorian chant cannot be over emphasized or under-estimated when it comes to liturgy in the Roman Catholic Church. It touches all exigencies of the liturgy. It is the supreme model of sacred music, and also today, Gregorian chant continues to be an element of unity in the Roman Liturgy. 
Note: An example of Gregorian chant sheet music 'Asperges $M e^{\prime}$ is given in the Appendix at the back of this paper.

\section{Sacred Polyphony}

The Fathers of the Second Vatican Council addressed polyphony by stating, "Other kinds of sacred music, especially sacred polyphony, are by no means excluded from liturgical celebrations, so long as they accord with the spirit of the liturgical action." The term "polyphony'(from the Greek for "many sounds" is used to describe music that employs simultaneous yet independent melodies. Polyphony is a type of music where a typical choral piece has four, five, or six voice parts of nearly equal melodic interest: each presents the same melodic idea in turn, as in a round. This can occur in secular or sacred songs.

The Church's vast collection of polyphonic songs - usually called motets -grew out of Gregorian Chant in the Late Middle Ages (1100-1400 AD). It developed further in the Renaissance (1400 -1600 AD), owing to the works of composers such as Tomas de Victoria, Orlando de Lassus, and also Giovanni Perluigi de Palestrina, who is the best-known composer of polyphony, and whom Pope Pius X praised in his 1903 motuspropio called Tra le Sollecitudini.

Note: An example of polyphonic sheet music by Palestrina called 'Dona Nobis' is given in the Appendix at the back of this paper.

\section{Instrumental Music}

Instrumental music also has a place in the liturgy (as 'Musicam Sacram' acknowledged), but it plays second fiddle (so to speak) to sung texts. Initially, in the Middle Ages, the Church frowned on instruments because of their earlier role in pagan rites, and because of their noise which they said distracted worshippers. But after 
about $1100 \mathrm{AD}$, instruments were used increasingly in the Church, but Organ was most prominent. At first, it was a primitive instrument; the keys were operated by heavy blows with the fist. It was so loud that it could be heard for miles around. Gradually, it evolved into a flexible instrument that could play polyphonic music.

Incidentally, the only instrument permitted by name at the Vatican Council II is the Pipe Organ which is to be held in high esteem (magno in honorehabeatur), for it is the traditional musical instrument which adds wonderful splendor to the Church's ceremonies and powerfully lifts man's mind to God and to higher things. In terms of other instruments, these also may be admitted for use in the divine worship, with the knowledge and consent of the competent authority. Yet this consent can be given only on condition that the instruments are suitable, or can be made suitable for sacred use, accord with the temple, and truly contribute to the edification of the faithful.

\section{The Decline in Liturgical Music in Recent Time}

It is no longer a hidden fact that there has been a great decline in liturgical music and Church music as a whole, for a long time now. The major reasons why there came about a decline in the beauty of liturgical music are due to the following factors.

\section{Lack of enlightened and trained ministers of the Church in what liturgical music really entails}

Pope Pius X insisted in particular on the musical training of clerics. The Vatican Council II also said in this regard, "Great importance is to be attached to the teaching and practice of music in seminaries, in the novitiate houses of studies of Religious of both sexes, and also in other Catholic Institutions and schools." Since 
the ministers of the Church are pastor of souls and the guide that the people of God have, when they are well trained in sacred music, they will know how to guide the choir, composers of sacred music, music directors, and the entire people of God, so that the proper guidelines and instructions laid out by the Church, for the glory of God, and for the sanctification of the faithful would be properly followed.

\section{Lack of musical training and professionalism among many Church musicians (composers, music directors, choir masters, choristers, etc.)}

The Vatican II Constitution exhorts thus: "Choirs must be assiduously developed, especially in Cathedral Churches". The choir is responsible for the correct performance of its part, according to the differing types of songs, to help the faithful to take an active part in the singing. Therefore, choirs are to be developed with great care, especially in cathedrals and other major Churches, in seminaries and in religious houses of study. In the task of training, a special role is played by schools of sacred music, which St Pius X urged people to support and encourage, and which the Second Vatican Council recommended to be set up wherever possible.

\section{Misinterpretation of Inculturation}

The Gospel of Jesus Christ must be preached to all nations, and the liturgy must be celebrated in each culture. Culture affects every aspect of the Church, including evangelization, Catechesis, the liturgy and prayer life, even the language used in various regions of the globe. The Church is one but the Church has to express itself in various cultures. 
The word 'Inculturation' became popular in the wake of Vatican Council II. The Church since the Vatican Council II (1963-1965), accommodates in her rites the languages and certain elements specific to individual cultures, a custom extending back to the early Church. The practice of incorporating appropriate cultural elements into the liturgy is also known as Inculturation. However, most Roman Catholic services have been celebrated in the language of each country. In the aspect of liturgical music, people could then sing and compose liturgical songs in their own languages, and also use their own style of musical instruments, all to the glory of God.

But above all, inculturation in the aspect of sacred music was not meant to destroy the beauty of sacred music. This everyone must understand, for many misunderstood it. For inculturation to be proper in whatever aspect it concerns, it must respect the rules and guidelines of the Church. Musicians and composers of sacred music must, even though they add some elements of their culture, follow the rules of Sacred Church Music. In this regard, Pope John Paul II wrote in his 2003 Chirograph on Sacred Music, "those elitist forms of "inculturation" which introduce into the liturgy ancient or contemporary compositions of possible artistic value, but that indulge in a language that is incomprehensible to the majority, should be avoided." Quoting Pope Pius X, he went further, "While every nation is permitted to admit into its ecclesiastical compositions those special forms which may be said to constitute its native music, still these forms must be subordinate in such a manner to the general character of Sacred Music, that nobody of any nation may receive an impression other than good on hearing them. In order words, the sacred context of the celebration must never become a laboratory 
for experimentation or permit forms of composition and performance to be introduced without careful review."

\section{Problems that Developed in Liturgical Music and Their Consequences}

As a result of the above mentioned factors, serious problems evolved in Liturgical music, and many consequences followed. This tragic loss of beauty in liturgy, we should not dismiss lightly for it has caused and is still causing a lot of mishap and lose of decorum in the house of God. We are realizing more and more clearly that silence is part of the liturgy. We should expect the liturgy to give us a positive stillness that will unite us with the Divine. We all know that we should offer the very best to God in our worship of Him, yet what we often experience, sadly, is tawdriness and mediocrity, kind of a second-hand sacrifice. Below are listed some of the problems:

i. The Gregorian chant, which the Church holds in high esteem, was allowed to sink into disuse. It has been ignored, left in the museum, presented only in concert halls or only during music competitions. Sometimes it is out-rightly despised and scorned. And some people see it as dull whenever it is being used in the liturgy. And when it is sung by the choir, it is badly rendered because of lack of practice and lack of knowledge of the rules guiding the chant.

ii. Hip-hop, Pop, Reggae, High-life, R\&B, and other secular music tunes, which should be rather meant for social gatherings or parties, are now used for liturgical tunes during Holy Mass. Though Sacred and Secular music were both instituted by God, yet both should never contradict each other. 
iii. When the Body of Christ is raised during consecration, some priests sing songs which should not be part of the liturgy, when there should be silence for the faithful to adore their Lord.

iv. Modern choirs do not focus their songs on God and the good of the souls of the faithful, but rather on the success of their performance before the people of God. Instead of singing solemn songs that draw souls to God, they sing classical songs that should rather be performed in the theater. St. Augustine of Hippo would say, "When it happens to me to be more moved by the singing than by what is sung I confess to have sinned criminally".

v. Entroits are no longer sung by the choir at the beginning of Masses.

vi. Choirs and their Directors lack books of responsorial psalms; that is also the reason why they use any tunes they come across, including secular tunes for Responsorial Psalms and Alleluia choruses.

\section{What Can be Done to Remedy the Situation?}

On various occasions, Pope John Paul II stressed the need to purify worship from ugliness of style, from distasteful forms of expression, from uninspired musical tests which are not worthy of the great act that is being celebrated, to guarantee dignity and excellence to liturgical compositions. In quoting St Pius X, Pope John Paul II went ahead to say that "Music destined for sacred rites must have 'holiness' as its reference point. Sacred music increases in holiness to the degree that it is intimately linked with liturgical action. Not all without distinction that is outside the temple (profanum) is fit to cross its threshold". Pope Paul VI also wisely said, "If music - instrumental and vocal -does not possess at the 
same time the sense of prayer, dignity and beauty, it precludes the entry into the sphere of the sacred and the religious."

It is now very clear to see the reason why the Roman Catholic Church sees Gregorian Chant as the highest model of Church music, because it has a prayerful nature and possess the all the qualities of liturgical music - Holiness or Sacredness, Artful Beauty and Universality.

Realizing the decline in Liturgical music should we then fold our arms and watch Liturgical music decline continuously? Not at all! That was why many Popes, Bishops, Priests, Religious, the people of God, and music scholars have worked hard to see that sacred music in the Church is resuscitated.

\section{Below are some of the actions and instructions that may go a long way to help in remedying the situation:}

- It will be highly commendable if Church musicians, Church ministers and lay faithful alike to read from time to time, Church documents, especially those concerning the sacred music, so as to know what the Church wants and has directed concerning sacred music, and then to work according to the directives given. Ignorance of the rules of the Church is part of the main problems we have.

- Motivated by a strong desire 'to maintain and promote the decorum of the house of God', St. Pope Pius X, in 1903, promulgated the Motu Propio, "Tra Le Sollecitudini" (Instruction of Sacred Music), with the purpose to renew sacred music during liturgical services. And in it, he offered the Church practical guidelines in that sector of the Liturgy; of which if followed, there would be a lot of improvement on music in the liturgical celebrations. 
- Quoting the words of Pope Pius X, Pope John Paul II said: "The more closely a composition for Church approaches in its movement, inspiration and savor, the Gregorian melodic form, the more sacred and liturgical it becomes; and the more out of harmony it is with the supreme model, the less worthy it is for Divine worship." In that light, we can say that there are some Nigerian sacred music composers who have after all listened to the instructions of the Church and Her authorities concerning the composition of liturgical music even with the dawn of inculturation. Examples are: Reverend Fr. C. Ezenduka, Mrs. Dorothy Ipere, and many others.

- For the sake of reform of Sacred Music, Pope Pius X established in Rome in 1911, the 'Pontificiolstituto di Musica Sacra' (Pontifical Institute of Sacred Music). Many other Dioceses in the Roman Catholic Church have taken a leaf from Pius $\mathrm{X}$, and established many other schools that are really striving to impart better knowledge of good liturgical music. Some examples are as follows:

i. Mater Christi Music Academy, Amawbia, Anambra State, Nigeria - Established in 2014, by the Sisters of the Immaculate Heart of Mary Mother of Christ Congregation (IHM)

ii. Cecilian Academy Of Sacred Music: Established in 2013 in the Archdiocese of Lagos, Nigeria.

\section{Effect of Good Liturgical Music on Leadership}

Leadership comes with responsibilities. Liturgical music exists to serve a purpose in worship therefore; the basic role of a liturgical musician is to help actualize the purpose of liturgical music. In this context, leadership responsibilities are spread out to everyone in a way, I mean everyone in the worshipping community. This will be 
further explained in three-grouped categories in a Liturgical musician - Choir - Congregation format.

\section{Liturgical Musician}

The role of a liturgical musician is leadership oriented. Liturgical musician can come in different ways such as a composer, music director, and choir master. It is at this level that the choice of the music to be used in the liturgy is made either as a composer who wrote the music or as the music director or choir master who directs and teaches the song. It is highly expected for the people at this level to have a good grasp of the necessary skills accordingly ranging from the skill of a composer to be able to bring forth music that richly reflects Holiness, Artful Beauty and Universality. In as much as individual styles are bound to surface at this level it should however not be the main focus and centre of attention of the music. It is pertinent that the composer composes music to effectively convey the message which it is intended to instead of being a source of distraction. The composer should not compose for the liturgy in other to just remain relevant in the art of composition but should compose to minister appropriately the intended message. By doing this, he or she is just as a good leader putting great service void of selfishness to effectively serve a purpose of which he is intended. Similar approach is also required of the music director who interprets the work of a composer. He or she should have in mind that the music is for worship and not for entertainment and as such should he or she interpret it.

\section{The Choir}

Through this medium the works of the composer and interpretations of the music director are conveyed. There is a great need for a level of awareness of the requirements of good liturgical 
music at this level. It is only a sign of good leadership if someone or some people at this level can ask some necessary questions to always help keep the decision making of the former group on the right track if not it will just reflect an existence of tyranny. There is need for a good rapport between the former and current. Remember it is only when this level of people are well informed that they would ask necessary questions.

\section{Congregation}

This entails the general worshipping community. There is also a need for a level of awareness for this group. Music is very powerful that one would consciously or unconsciously respond to its sound even when what is being played is not required at that point in time. The response of the congregation to a song in the liturgy speaks volume. It has been noticed over time that the liturgy has become more of a dance hall than what it should be because the congregation are always eager to dance and clap to every song no matter what purpose it serves. Yes, obviously it could be the fault of the composer or the music director or the choir master. However, I think the congregation also has a role to play and they can only play that role if they know the right thing to be done.

They have a simple task to make complaint either to the liturgical musicians or to the priest or minister in charge who will in turn reach out to the appropriate persons. This goes on to show that leadership job is collective in the sense that it needs everyone to be active in their own capacity for things to effectively work out. In every little sect of life there is a training going on. All these training are supposed to impact positively in enabling good human relationship among the people which will for instance make it possible for a Christian to relate well with a Muslim. In summary, 
when a liturgical music serves its purpose, it has good effect on the people by helping them to reflect more on the messages passed during worship. Since music has the power to emphasis more what words cannot say, it is only beautiful that an informed liturgical musician harness this power to positively affect the lives of the people at his disposal who will in turn in one way or the other affect the lives of people they meet elsewhere; it is all about forming the human for the greater glory of God and for common good (Ad Majorem Gloriam Dei).

\section{Conclusion}

When evaluating a hymn or piece of music for the choir, we should ask whether the words and music are about us. This should be fairly obvious and yet when you open a contemporary Catholic hymnbook you will find an extraordinary number of hymns which are not about God, but about the community, its need and its mission. The lyrics of liturgical music should be fully Catholic and complement the liturgy. Music is not chosen just because we like this song or that song, instead the lyrics should express theology. The words should not only communicate Catholic truth, they should also echo the readings and themes of worship.

Ultimately, liturgical music serves the liturgy; the liturgy does not serve the music. The organ, the choir and congregational singing is all subservient to the action at the altar. Therefore music, like every other aspect of the liturgy, should not draw attention to itself - either because it is so terrible or because it is so marvelous. All aspects of the liturgy must lead to God.

The renowned writer and theologian, G.K. Chesterton said, "We do not want a Church that will move with the world. We want a Church that will move the world." Only by returning to the truly transcendent music of the Church tradition will liturgy once again 
become beautiful, as it is meant to be. Rather than bringing the clamor and noise of the world into the Church, we should rather be spiritually nourished and fed on heavenly food, so that we may be sent forth to bring Christ's grace and truth out into the fallen and broken world, which stands in dire need of salvation. We can also lead by first showing examples as good followers.

\section{Cordis-Mariae Achikeh \& Raphael Umeugochukwu}

Department of Music, Nnamdi Azikiwe University, Awka ri.umeugochukwu@unizik.edu.ng

\section{Bibliographies}

Catholicnewsagency.com

Cecilian Academy of Sacred Music: Archdiocese of Lagos, Nigeria (www.cecilianacademyofmusic.com)

Chirograph of the Supreme Pontiff John Paul II for the Centenary of Motu Propio "Tra Sollecitudini” On Sacred Music, 2003.

Cicognani, C., \& Carinci, A. (1959). Instruction on Sacred Music and the Sacred Liturgy. The Furrow, 10(1), 43-67. Retrieved from www.jstor.org/stable/27657555

Nationalcatholicregister.com

New Catholic Igbo Hymn Book: Revised Edition, 2005

Plain Chant - From the Liber Usalis (Onitsha Archdiocese, $27^{\text {th }}$ November, $1994-1^{\text {st }}$ Sunday of Advent).

Sacrosanctum Concilium (Vatican council II Constitution on the Sacred Liturgy).

The Sacred Congregation of Rites (Instruction on Music in the Sacred Liturgy). London: Catholic Truth Society.

Tra Le Sollecitudinion Sacred Music by Pope Pius X - November 22, 1903. 